\title{
Synthesis of MgO Nanoparticles and Their Antibacterial Properties on Three Food Poisoning Causing Bacteria
}

\author{
Nadia Baniasadi, Ashraf Kariminik* (D), Sayed Mohamad Reza Khoshroo
}

Department of Microbiology, Kerman Branch, Islamic Azad University, Kerman, Iran

$\underline{10.30699 / i j m m .13 .5 .379}$

\section{ABSTRACT}

Background: Application of nanoparticles in the removal of pathogenic bacteria is very important. The use of these materials can be appropriate for controlling pathogens and food-borne diseases. The purpose of this study was to synthesize magnesium oxide nanoparticles and investigate its antibacterial effect on several bacteria causing food poisoning.

Materials \& Methods: Oxide magnesium nanoparticles are synthesized by chemical deposition method. In order to control the quality and morphology of samples, XRD and SEM methods were used. The effect of different concentrations of nanoparticles on Staphylococcus aureus, Salmonella enterica and Bacillus cereus was evaluated by Agar well diffusion technique and the antibiotic resistance patterns of the bacteria used were also examined.

Results: MgO nanoparticles had an extensive antibiotic resistance but were effective on all bacteria and the minimum inhibitory concentration of growth on Staphylococcus aureus, Salmonella enterica and Bacillus cereus was $0.75,1.25$, and 5 $\mathrm{mg} / \mathrm{mL}$ and the minimum bactericidal concentration of them were determined to be $0.15,2.5$ and $10 \mathrm{mg} / \mathrm{mL}$, respectively.

Conclusion: $\mathrm{MgO}$ nanoparticles exhibited remarkable antibacterial activity against food poisoning causing bacteria and can be used as an antibacterial agent more effectively.

Keywords: Magnesium oxide Nanoparticles, Food poisoning, Antibacterial properties. Preservative

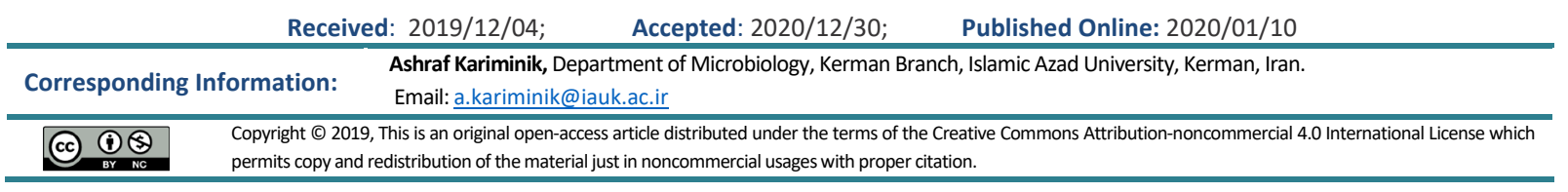

Use your device to scan and read the article online

Baniasadi N, Kariminik A, Khoshroo S M R. Synthesis of MgO Nanoparticles and Their Antibacterial Properties on Three Food Poisoning Causing Bacteria. Iran J Med Microbiol. 2019; 13 (5) :379-390

Download citation: BibTeX | RIS | EndNote | Medlars | ProCite | Reference Manager | RefWorks

Send citation to: $\otimes_{\text {Mendeley }} 2$ zotero $\mathbb{H}_{\text {RefWorks }}$

\section{Introduction}

Today, drug resistance in many bacteria is significantly increased. Bacterial resistance to antibiotics is one of the biggest challenges that threatens human health in the modern age (1). Prevention of food spoilage and control of food poisoning pathogens are usually done with preservatives that have harmful effects on human health or increase the resistance of microbes to antimicrobial agents such as antibiotics $(2,3)$. Nanoparticle technology is a new technology that is sweeping the whole world, and more precisely, nanotechnology is not part of the future, but it is the future. Nanotechnology is not a new discipline, but rather a new approach in all disciplines for which they have listed applications in the various fields of food, medicine, medical diagnosis and industry (4). The nanoparticles are about 1 to $100 \mathrm{~nm}$ in diameter and have unique surface composition, size, shape, and chemical properties. The fine particle design can be used to target germs (5). These particles have been widely used as antimicrobial agents for the control and treatment of microbes and this may suggest the use of nanoparticles for antibiotic replacement (6). Nanoparticles have antibacterial properties due to their high surface-to-volume ratio and small size, penetrating microorganisms, as well as having photocatalytic, 
catalytic and ionic effects, and are widely used in the fight against pathogenic microorganisms such as bacteria, fungi, and viruses $(7,8)$. MgO nanoparticles of noninorganic metal oxides have antibacterial properties and their important advantages are their non-toxicity and rapid, easy and low cost synthesis. The nanoparticle has been identified as a safe substance by the US Food and Drug Administration (21CFR184.1431) $(9,10)$. Bacteria such as Staphylococcus aureus, Bacillus cereus and Salmonella enterica play an important role in food poisoning (11). Enterotoxins of $B$. cereus cause diarrhea and nausea. It grows in foods such as rice, cereals, dairy and meat and by producing two types of enterotoxins, it causes food poisoning and remains in pasteurized milkdue to the presence of spores as an opportunistic agent $(\mathbf{1 2 , 1 3 )}$. In addition, Salmonella species, like $S$. enterica, are currently the most common cause of food poisoning (14). The aim of this study was to synthesize $\mathrm{MgO}$ nanoparticles and investigate their antibacterial effects against three food poisoning causing bacteria.

\section{Materials and Methods}

\section{Synthesis and Characterization of MgO Nanoparticles}

Chemical deposition method was used to prepare magnesium oxide nanoparticles $(15,16)$. Therefore, 0.21 $\mathrm{g}$ magnesium nitrate and $2 \mathrm{mmol}(0.44 \mathrm{~g})$ sodium hydroxide was heated in a $100 \mathrm{~mL}$ human under stirring conditions at $60^{\circ} \mathrm{C}$ for $45 \mathrm{~min}$. In another flask, $4 \mathrm{mmol}$ $(0.30 \mathrm{~g})$ of sodium dodecyl sulfate surfactant as a stabilizing source in $10 \mathrm{~mL}$ methanol solvent was placed on a magnetic stirrer at $60^{\circ} \mathrm{C}$ for $30 \mathrm{~min}$ at a pH of 8 to 9 . The magnesium oxide solution was then mixed with a surfactant solution in a $100 \mathrm{~mL}$ Erlenmeyer flask and incubated at $60^{\circ} \mathrm{C}$ for one hour. The resulting solution was first placed in an ultrasonic bath at 60 watts and then placed at $60^{\circ} \mathrm{C}$ to stabilize the particles. After deposition, the solution was discarded to remove the precipitate from the reaction solution. To remove impurities, the precipitate was washed several times with double distilled water and ethanol, and dried in a vacuum oven at $60^{\circ} \mathrm{C}$ for 24 hours. Quality control and morphology of magnesium oxide nanoparticles made by XRD (X-ray diffraction) and SEM (Scanning electron microscope) methods were used $(15,16)$.

\section{Antibacterial Effects of MgO Nanoparticles}

Antibacterial effects of magnesium oxide nanoparticles against three food poisoning bacteria including Staphylococcus aureus, Bacillus cereus and Salmonella enterica isolated from food samples were done by Agar well diffusion method (17). Different concentrations of $5,10,20,40,2.5,1.25,0.62,0.31$ and $0.15 \mathrm{mg} / \mathrm{mL}$ of magnesium nano oxide made in dimethyl sulfoxide and methanol (v/v) solvents was prepared by doubling the dilution in each step (18). Each bacterium was prepared from a standard suspension equivalent to a $0.5 \mathrm{McF}$ arland's solution in sterile normal saline. The wells were embedded in a $4 \mathrm{~mm}$ diameter well in Muller Hinton agar medium and $20 \mu \mathrm{L}$ of each nanoparticle concentration was poured into each well. This was done at concentrations of 5,10,20,40, 2,5, 1/25, 0.62, 0.31 and $0.15 \mathrm{mg} / \mathrm{ml}$ of magnesium nano oxide were performed separately with three replications. Plates were incubated at $4^{\circ} \mathrm{C}$ for one hour, and after absorbing the nano solution into the culture medium, they were incubated in the oven at $37^{\circ} \mathrm{C}$ for $24 \mathrm{~h}$. The minimum inhibitory concentration (MIC) and minimum bactericidal concentration (MBC) of the synthesized nanoparticles against all three bacteria were determined. After incubation for 24 hours at $37^{\circ} \mathrm{C}$, the diameter inhibition zone was measured in millimeters. It should be noted that solvent dimethyl sulfoxide and methanol were used as negative control. All the media and chemicals used were provided by Merck German Company (19).

\section{Determination of Antibiotic Resistance Pattern of Bacteria}

The purpose of the antibiogram was to determine the antibiotic resistance pattern of the bacteria used from wild strains isolated from food. For this purpose, disk diffusion method was used (20). A standard concentration of 0.5 standard McFarland was prepared from each bacterium Antibiotics of cefalexin (30 mcg), amikacin (30 mcg), neurofloxacin (10 mcg), ciprofloxacin $(5 \mathrm{mcg})$, gentamicin (10 mcg), ampicillin (20 mcg), sulfamethoxazole (10 mcg) and amoxicillin ( $25 \mathrm{mcg}$ ), made in Pars Tab Company, Iran. After incubation for $24 \mathrm{~h}$ at $37^{\circ} \mathrm{C}$, the diameter of inhibition zone was measured in $\mathrm{mm}$.

\section{Results}

\section{Results of Quality of Synthesized MgO Nanoparticles}

Identification and analysis of samples of $\mathrm{MgO}$ Nanoparticles made by XRD and SEM methods showed that these particles were spherical in shape with a diameter of about $64.23 \mathrm{~nm}$ and were well dispersed (Figure 1).

X-ray peaks also showed that the sample was highly purified in the crystalline phase. The X-ray pattern obtained from magnesium oxide microstructures shows that the structure in question is high purity without being amorphous with the JCPDS structural code. 01-1235 is formed (Figure 2).

The MgO nanoparticles synthesized against all three $S$. aureus, B. cereus and S. enterica were effective at low concentrations based on the results shown in Figure 3. 


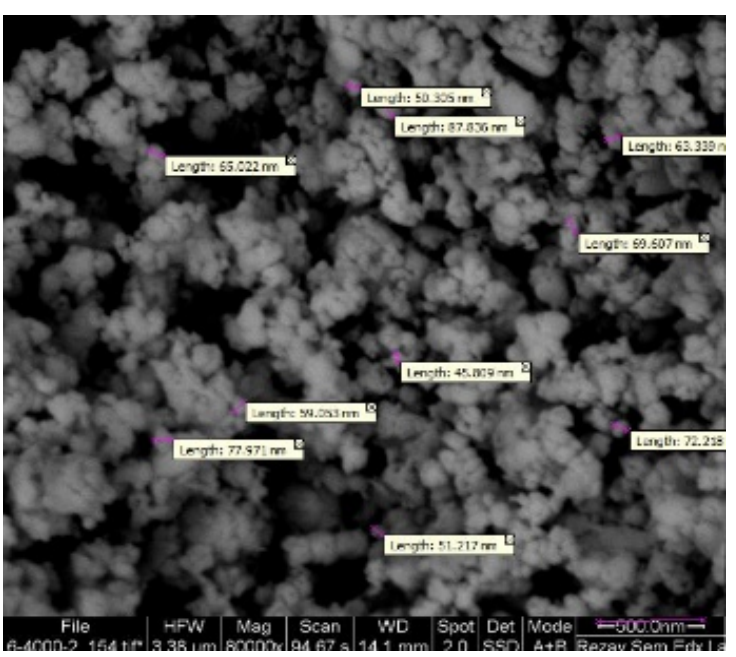

Figure 1. Observation of magnesium oxide nanoparticles made by scanning electron microscopy (SEM)

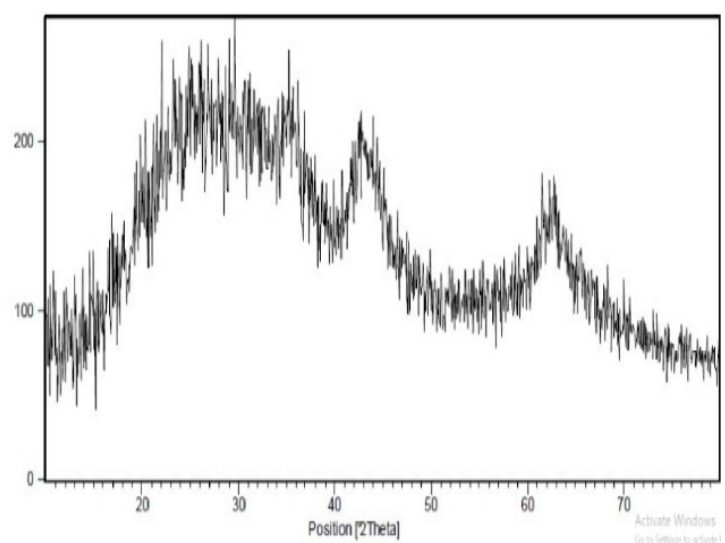

Figure 2. X-ray diffraction pattern of $\mathrm{MgO}$ nanoparticles Antibacterial Properties of MgO Nanoparticles

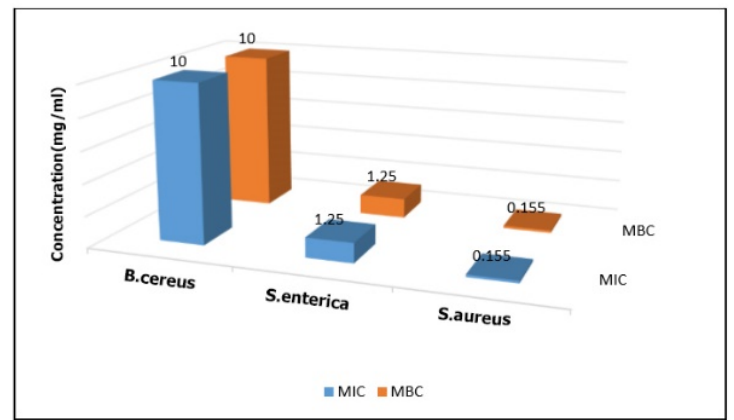

Figure 3. MIC and MBC of MgO nanoparticles against 3 bacteria

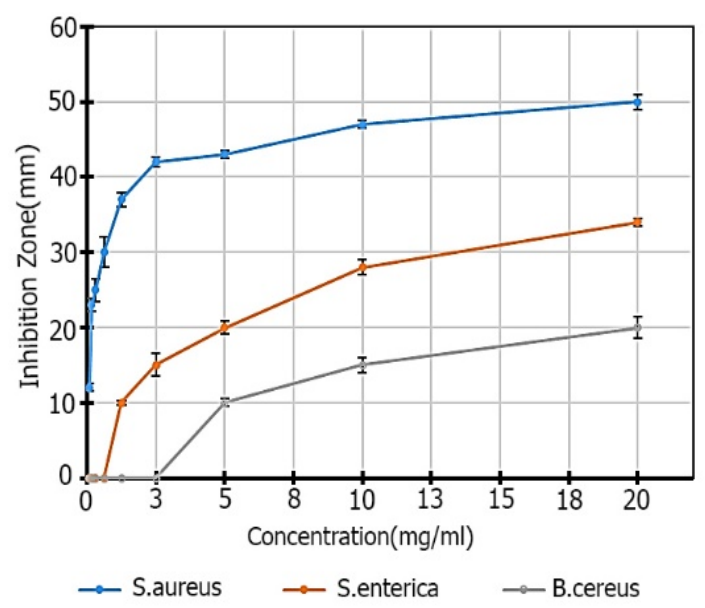

Figure 4. Comparison of the average diameter of inhibition zone $(\mathrm{mm})$ based on the concentration of nanoparticles $(\mathrm{mg} / \mathrm{mL})$

The inhibition zone diameter increases with increasing concentration of magnesium oxide nanoparticles. Table 1 shows the mean diameter of non-growth zone of magnesium oxide nanoparticles compared to the three bacteria. The results of analysis of variance of mean inhibition zone $(\mathrm{mm})$ diameter based on concentration of nanoparticles $(\mathrm{mg} / \mathrm{mL})$ are shown in Table 2 .

Table 1. Average inhibition zone diameter $(\mathrm{mm})$ based on concentration of nanoparticles $(\mathrm{mg} / \mathrm{mL})$.

\begin{tabular}{c|cccc} 
Bacteria & \multicolumn{2}{c}{ Concentration } & & \\
& & & SDain & SD \\
\hline \multirow{5}{*}{ S. aureus } & 20 & 50.00 & 1.41 & 1.00 \\
& 10 & 47.00 & .71 & .50 \\
& 5 & 43.00 & .71 & .50 \\
& 2.5 & 42.00 & .99 & .70 \\
& 1.25 & 37.00 & 1.27 & .90 \\
& 0.62 & 30.00 & 2.83 & 2.00 \\
& 0,31 & 25.00 & 2.12 & 1.50 \\
& 0,15 & 23.00 & 1.13 & .80 \\
& 0,075 & 12.00 & .71 & .50 \\
\hline \multirow{5}{*}{ S. epterica. } & 20 & 34.00 & .71 & .50 \\
& 10 & 28.00 & 1.41 & 1.00 \\
& 5 & 20.00 & 1.13 & .80 \\
& 2.5 & 15.00 & 2.12 & 1.50 \\
& 1.25 & 10.00 & .42 & .30 \\
& 0.62 & .00 & .00 & .00 \\
& 0,31 & .00 & .00 & .00 \\
& 0,15 & .00 & .00 & .00 \\
& 0,075 & .00 & .00 & .00 \\
\hline & 20 & 20.00 & 2.12 & 1.50 \\
& 10 & 15.00 & 1.41 & 1.00 \\
& 5 & 10.00 & .71 & .50 \\
& 2.5 & .00 & .00 & .00 \\
& 1.25 & .00 & .00 & .00 \\
& 0.62 & .00 & .00 & .00 \\
& 0,31 & .00 & .00 & .00 \\
& 0,15 & .00 & .00 & .00 \\
& 0.075 & .00 & .00 & .00 \\
\hline \multirow{5}{*}{ cereus } & & & &
\end{tabular}


Table 2. Variance analysis of diameter average of inhibition zone $(\mathrm{mm})$ based on nanoparticles concentration $(\mathrm{mg} / \mathrm{mL}$ )

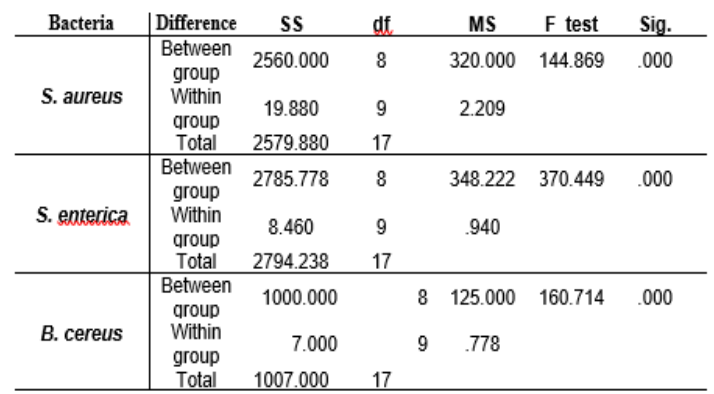

Minimum Inhibitory Concentration (MIC) of $S$. aureus, S. enterica and B. cereus were $0.075,1.25$ and $5 \mathrm{mg} / \mathrm{mL}$, respectively, and Minimum Bactericidal Concentration (MBC) of Magnesium Oxide Nanoparticles were 0.15, 2.5 and $10 \mathrm{mg} / \mathrm{mL}$ respectively (Figures 3 and 4 ). Comparison of mean inhibition zone diameter based on Duncan's method at $\alpha=0.05$ showed that the concentrations used on average zone diameter were significantly different for S. aureus up to concentration 10 and for bacteria. Others are significant up to a concentration of $20 \mathrm{mg} / \mathrm{mL}$ (Table 3).

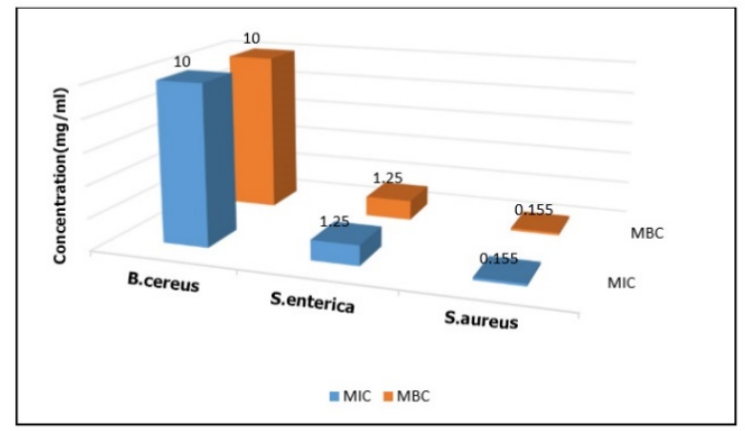

Figure 3. MIC and $\mathrm{MBC}$ of $\mathrm{MgO}$ nanoparticles against three bacteria

\section{Antibiogram Results}

The results of the antibiotic effect on three bacterial strains isolated from the studied samples showed that Staphylococcus aureus was sensitive to only two antibiotics cefalexin and amikacin and to neurofloxacin, sephroploxacin, gentamicin, Sulfamethoxazole and amoxicillin were resistant. Resistance to cephalexin, neurofloxacin and sulfamethoxazole was observed in $S$. enterica and resistance to cephalexin, sulfamethoxazole, amoxicillin was observed in Bacillus cereus.

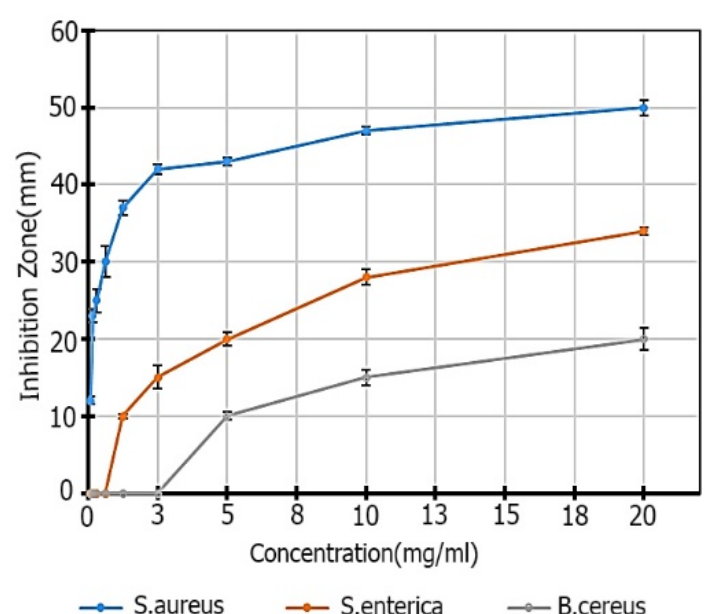

Figure 4. Comparison of the average diameter of inhibition zone $(\mathrm{mm})$ based on the concentration of nanoparticles $(\mathrm{mg} / \mathrm{mL})$

Table 3. Comparison of mean diameter of inhibition zone ( $\mathrm{mm}$ ) based on concentration of nanoparticles $(\mathrm{mg} / \mathrm{mL}$ ) by Duncan method at $\alpha=0.05$.

\begin{tabular}{|cccc|}
\hline Concentration & S. aureus & S. enterica & B. cereus \\
\hline 20 & a & a & a \\
10 & a & b & b \\
5 & b & c & c \\
2.5 & b & d & d \\
1.25 & c & e & d \\
0.62 & d & f & d \\
0.31 & e & f & d \\
0.15 & e & f & d \\
0.075 & f & f & d \\
Similar letters in each group did not differ significantly.
\end{tabular}

\section{Discussion}

The antimicrobial effect of the nanoparticles is due to their effect on the cell wall and the outer part of the bacterial cell and also because of its entry into the cell and its effect on the different internal parts of the bacterial cell. The nanoparticles initially absorb the negative charge on the outer surface of the bacterium due to the positive electron charge. This binding can both disrupt the bacterial electrolyte balance and can affect the respiratory cycle of the bacterial cells. In the latter case, the nanoparticles affect the proteins and DNA, the respiratory chain enzymes responsible for cell growth and disruption of replication, resulting in the formation of free radicals and reactive oxygen $(21,22)$. Synthesis of nanoparticles with the potential to inhibit the growth of germs called nano-antibiotics is of great importance $(23,24)$. The size of the nanoparticles is very effective in their antimicrobial activity and the smaller the size, the greater the antimicrobial effect is, plus the bacterial strain is effective in the sensitivity of the nanoparticles (25). In the present study, the antibacterial effects of 
magnesium oxide nanoparticles were chemically evaluated against three food poisoning bacteria and all of them were resistant to some antibiotics but even on magnesium oxide nanoparticles. The concentrations were very low. Similar research has been done by other researchers on the effects of magnesium nanoparticles. The mechanism of antibacterial activity of magnesium oxide nanoparticles against Escherichia coli and Pseudomonas aeruginosa and $S$. aureus. The minimum inhibitory concentrations were $0.5 \mathrm{mg} / \mathrm{mL}$ for E. coli and $1 \mathrm{mg} / \mathrm{mL}$ for $P$. aeruginosa and $S$. aureus. They recognized that the sensitivity of the bacteria to the nanoparticles was not only related to the cell wall structure but also to the lipid peroxidation and production of reactive oxygen species (26). Other researchers examined the antibacterial effect of magnesium oxide nanoparticles, with an average size of $20 \mathrm{~nm}$, on a number of bacteria, including $E$. coli, Salmonella and Campylobacter. Minimum inhibitory concentrations for E. coli, Salmonella and Campylobacter were 1,2 and $0.5 \mathrm{mg} / \mathrm{mL}$, respectively. At $2 \mathrm{mg} / \mathrm{mL}$ concentration Campylobacter was completely inhibited for $2 \mathrm{~h}$ and at 2 to $4 \mathrm{mg} / \mathrm{mL}$ growth of $E$. coli and Salmonella stopped for 6-8 $\mathrm{h}$ (27). In another study, the magnesium oxide nanoparticles and the natural antimicrobial substance polyelelisine had antimicrobial effects on two foodborne bacteria, E. coli 0157: H7 (35218 ATCC) and Listeria monocytogenes (ATCC 19118), and their use had a synergistic effect. It also reduced the minimum concentration of the two compounds (28). A study by Ansari Moghaddam et al., aimed to determine the cytotoxicity of magnesium oxide nanoparticles on 562 K leukemia K cells, showing that different concentrations of Mgo nanoparticles had no effect on normal and even carcinogen cells. An increase in the concentration of nanoparticles is not correlated with an increase in its effect on the cell lines studied. Therefore, magnesium oxide nanoparticles have no cytotoxic effect on human cells and have specific effects on microbial cells (29).The findings of the present study and other researchers indicated that magnesium oxide metal nanoparticles have very effective antibacterial properties and there is a direct relationship between the concentration of nanoparticles and the bacterial elimination rate and the antibacterial effect is a bactericidal effect. Magnesium oxide nanoparticles have no growth inhibitory (bacteriostatic) effects, and the nanoparticle solution appears to be diffused as microscopic particles and can easily penetrate into bacterial cells. In general, nanoparticles can also be one of the important pollutants in the toxicity of different parts of the body due to their physical and chemical properties as well as the positive properties seen in in vitro conditions. Assessing the type of exposure and identifying hazardous properties for nanoparticles requires consideration of safety and knowledge of the effects of these substances on humans and the environment, thorough understanding of the substances and their toxicological effects. Nanoparticles, like a double-edged sword, have beneficial and harmful effects. Although nanotechnology has revolutionized and expanded widely in many fields, however, reducing toxicity and the dangers of exposure to nanoparticles should be one of the main goals of this field.

\section{Conclusion}

Due to the antimicrobial effect that magnesium oxide nanoparticles have on food-borne bacteria, it can be considered as a good candidate for controlling microbial contamination of food in food antimicrobial packaging.

\section{Acknowledgement}

Hereby we express our gratitude to our colleagues at the Microbiology Research Laboratory, Islamic Azad University, Kerman Branch.

\section{Conflict of Interest}

Authors declared no conflict of interests. 


$$
\begin{aligned}
& \text { مجله ميكروبشناسى يزشكى ايران }
\end{aligned}
$$

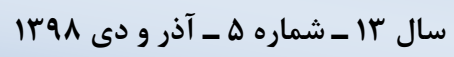

\author{
ناديا بنى اسدى، اشرف كريمى نيك*"iD)، سيد محمد رضا خوشرو
}

\begin{tabular}{|c|c|}
\hline جكسيله & اطلاعات مقاله \\
\hline 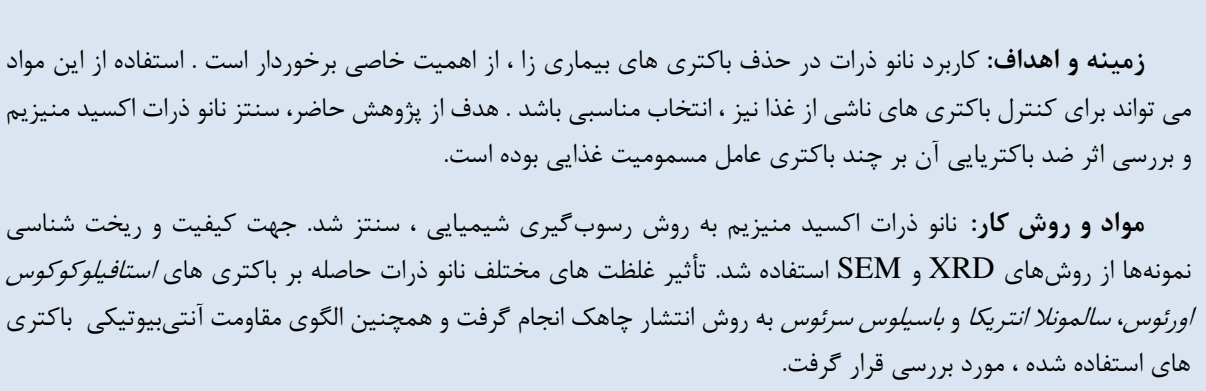 & 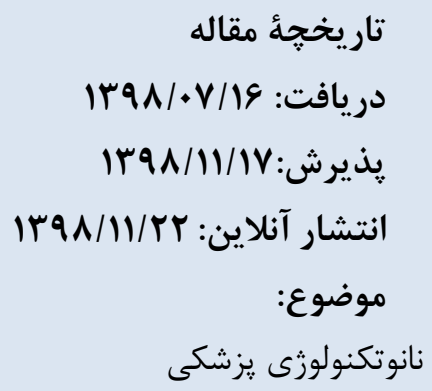 \\
\hline 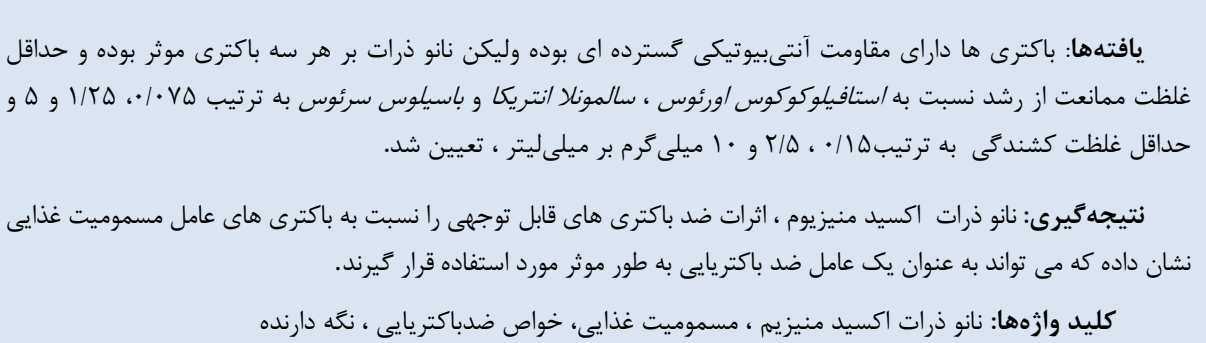 & 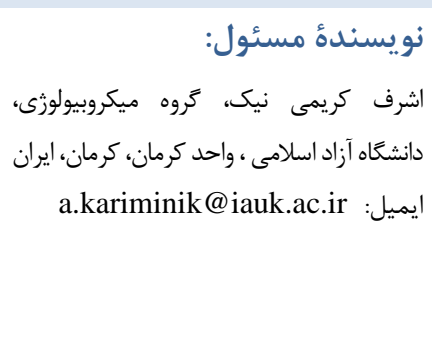 \\
\hline
\end{tabular}

كروه ميكروبيولوزى ، دانشًاه آزاد اسلامى ، واحد كر مان، كرمان، ايران

مقدمه

ذرات با قطرى حدود ا تا ـ . ا نانومتر بوده و داراى تركيب، اندازه، شكل و خصوصيت هاى شيميايى سطحى منحصر به فرد مى باشند. طراحى ريز ذره مى تواند در هدف قرار دادن ميكروبها كاربرد داشته باشد (ه). اين ذرات به عنوان عوامل ضدميكروبى به طور گسترده اي جهت كنترل و درمان ميكروب ها ، مورد استفاده قرار گرفته و

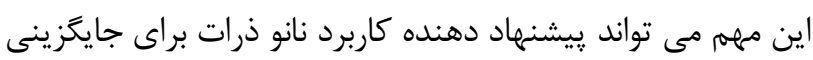

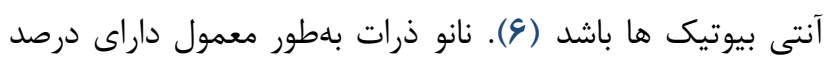

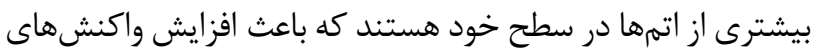
سطحى مىشود ـ نانوذرات به علت دارا بودن ويزگى هايى جون بالا بودن نسبت سط به حجم و كوخى بودن ابعاد، با نفوذ به ميكروار كانيسمها ويزگ فتوكاتاليستى، كاتاليستى و يونى، كاربرد گستردهاى در مبارزه با صارئ ميكرواور گانيسم هاى بيمارى زايى از قبيل باكترىها، قارجها، و وبيى،
امروزه مقاومت دارويى در بسيارى از باكترى ها به طور قابل توجهى افزايش يافته است. مقاومت باكترىها به آنتىبيوتيكها يكى بـى

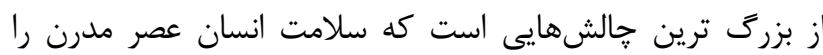
تهديد مى كند (1). ييشگيرى از فاسد شدن مواد غذايى و كنترل پاتوزن هاى عامل مسموميت غذايى معمولا با استفاده از مواد

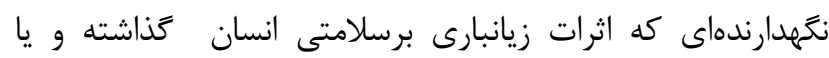
موجبات افزايش روند مقاومت ميكروب ها به عوامل ضدميكروبى از قبيل آنتىبيوتيكها ، مىشوند، انجام مى گيرد (ب-Y). فناورى نانو

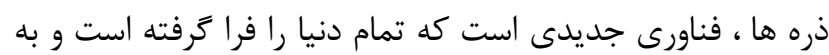
تعبير دقيقتر فناورى ريز بخشى از آينده نيست بلكه همه آينده است. فناورى ريز يك رشته جديد نيست، بلكه رويكردى جديد در

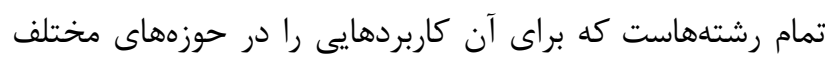
غذا، دارو، تشخيص يزشكى ،صنعت و غيره برشمردهاند (F). نانو 
و TF

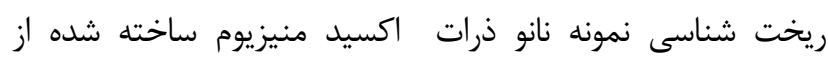

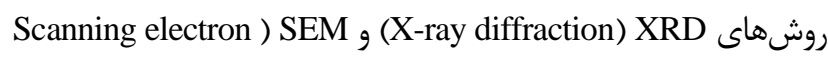
(microscope

\section{بررسى اثرات ضدباكتريايى نانوذرات اكسيد منيزيم}

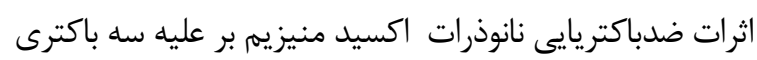

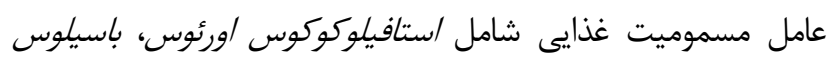

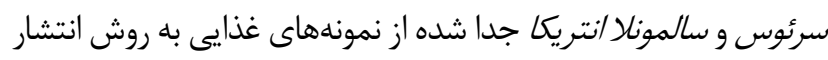

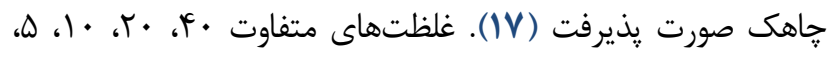

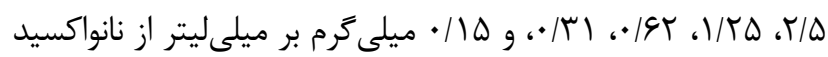

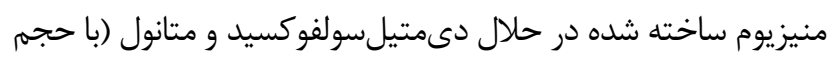

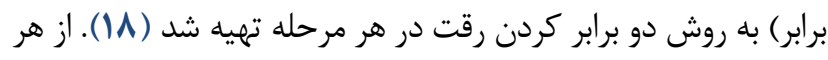
باكترى سوسيانسيون استاندارد معادل با كدورتى برابر با محلول نيم

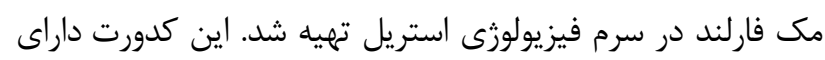

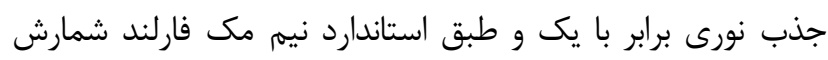

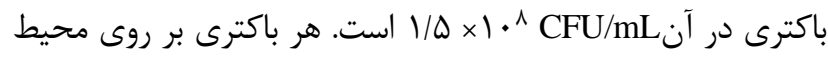

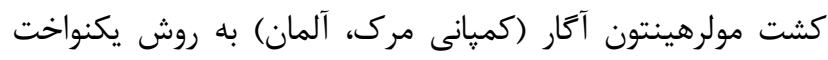

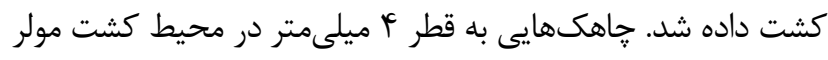

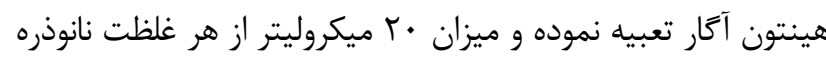

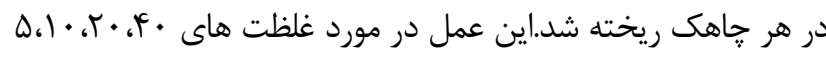

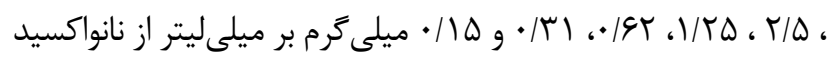

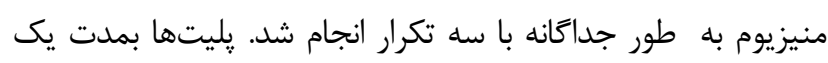

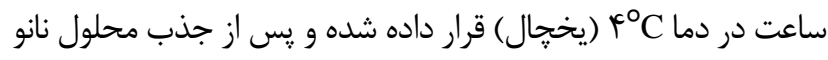

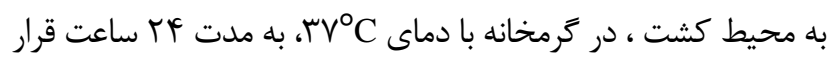

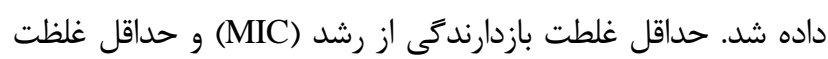

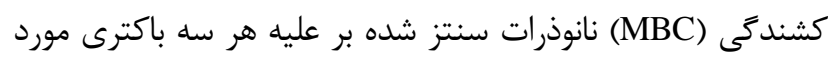

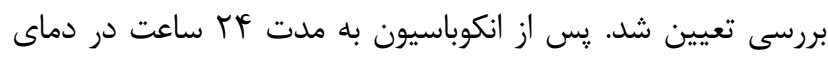
شوVC

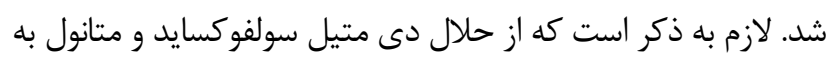

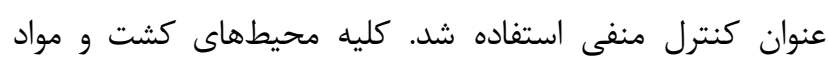

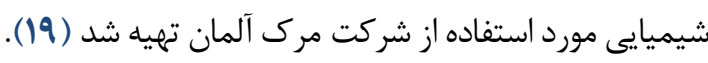

\section{تعيين الكوى مقاومت آنتىبيوتيكى باكترى هـا}

هدف از آنتىبيوكرام تعيين الكوى مقاومت انتيوتيكي باكترى آنتىبيوتيكى باكترىهاى مورد استفاده كه از سويههاى وحشى جدئ جدا شده از مواد

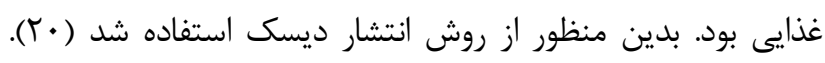

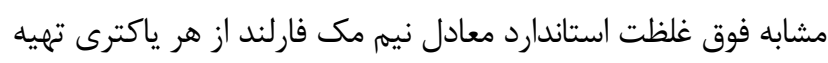

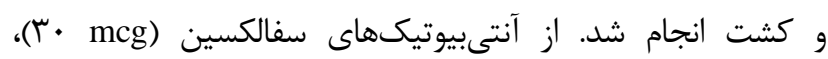

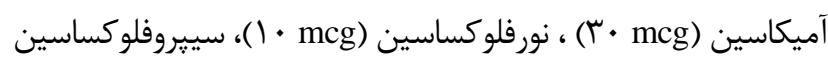

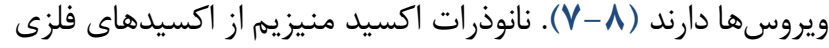

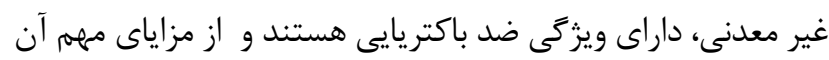

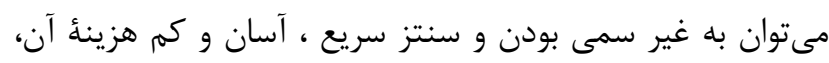

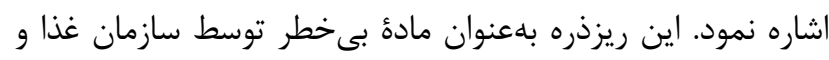

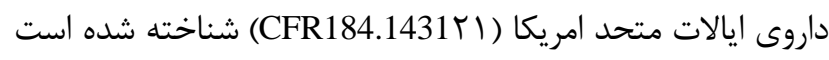

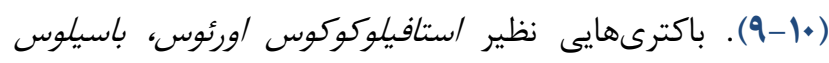

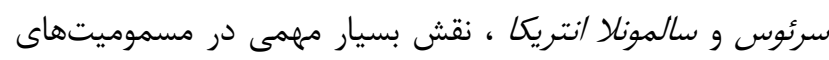

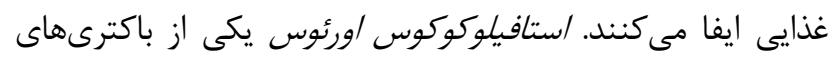

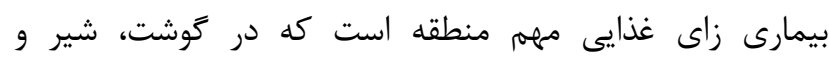

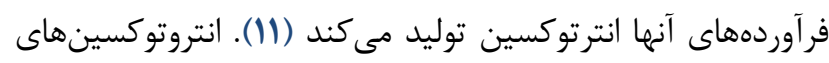

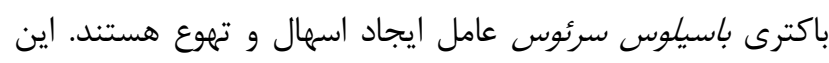

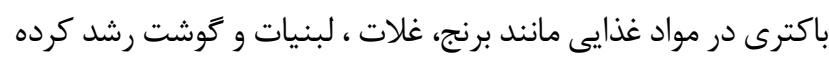

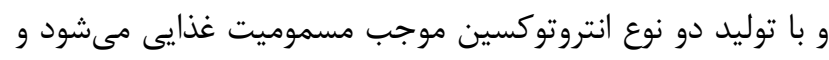

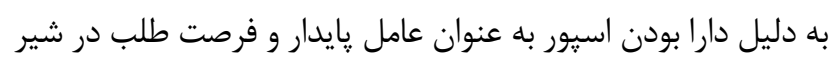

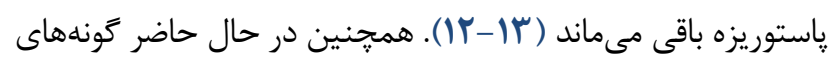

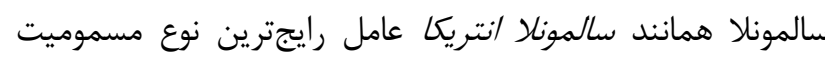

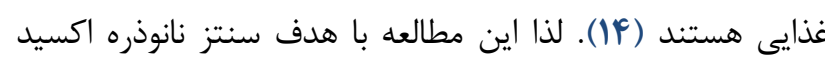

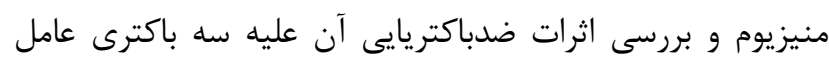
مسموميت غذايى صورت يذيرفته است.

$$
\text { مواد و روشها }
$$

\section{ساخت و شناسايى نانو ذرات اكسيد منيزيم}

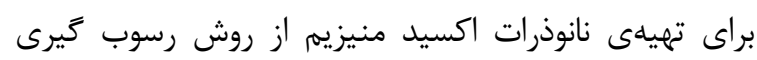

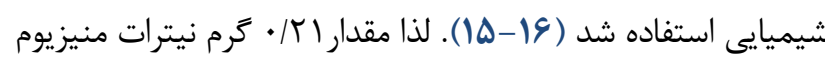

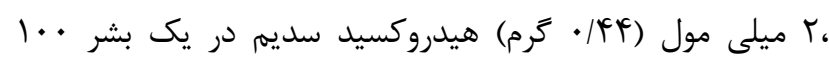

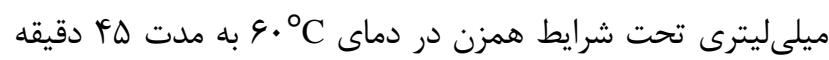

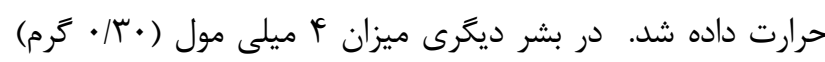

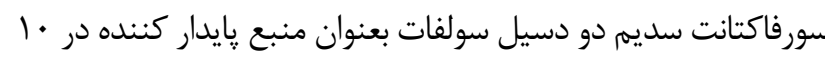

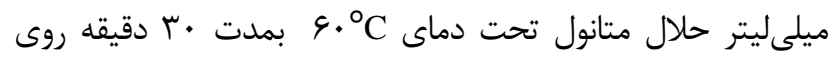

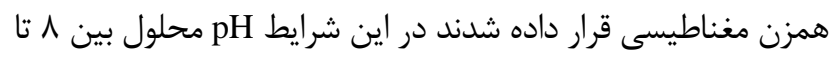

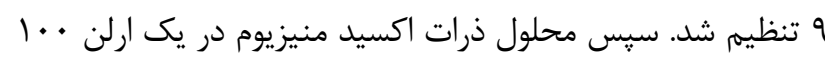

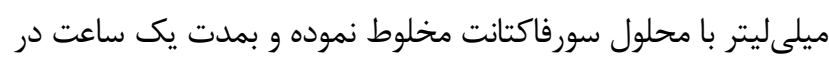

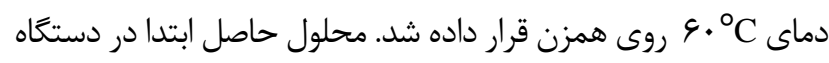

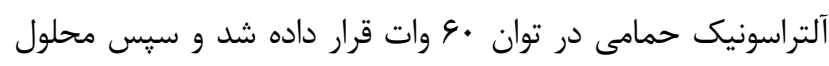
حاصل در دماى

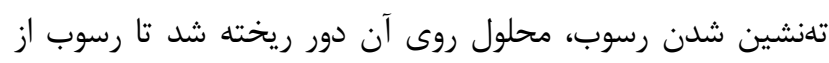

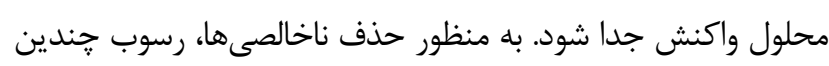
مرتبه با آب دوبار تقطير و اتانول شستسشو و در دماى 


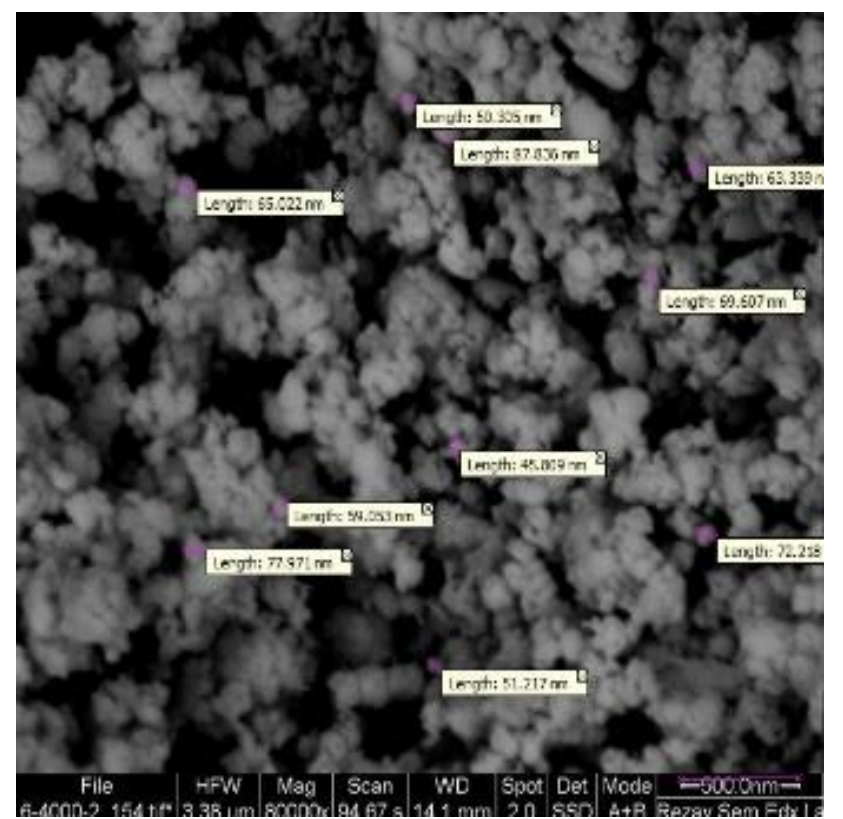

شكل 1. مشاهده نانو ذرات اكسيدمنيزيم ساخته شده توسط ميكروسكوٍ الكترونى (SEM) روبشى)

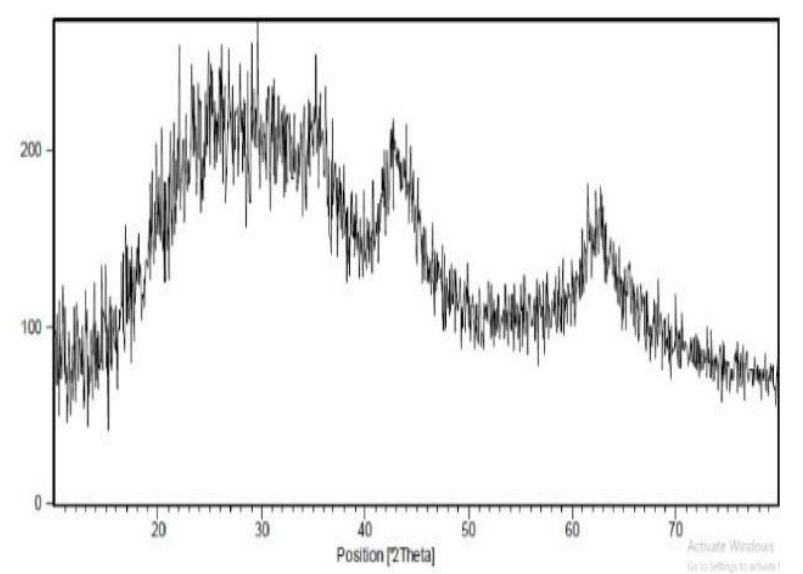

شكل r. الكوى ڤراش اشعه ايكس ساختار نانوذرات اكسيد منيزيم.

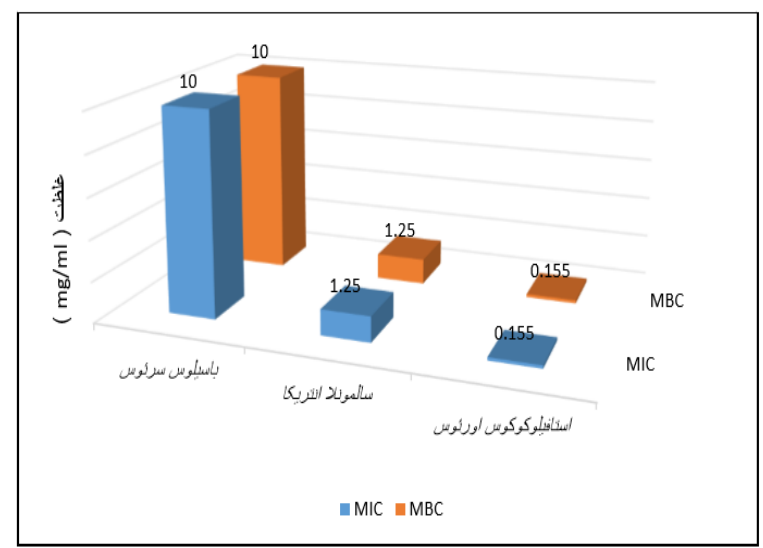

شكل r. حداقل غلظت ممانعت كننده از رشد و حداقل غلظت كشندكى نانوذرات

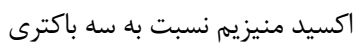

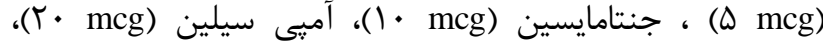

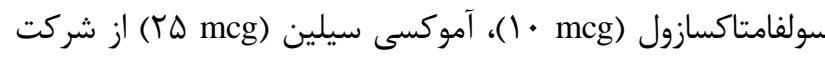

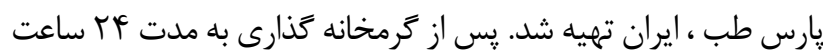
در دماى دماى تV

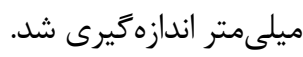

بافتهها

\section{نتايج كيفيت ساخت نانوذراتاكسيد منيزيوم} شناسايى و آناليز نمونه نانوذرات اكسيد منيزيوم ساخته شده بر ماري اساس روشهاى XRD و SEM نشان داد كه اين ذرات به شكل كروى با قطرى حدود س / / א نانومتر بوده و به خوبى يراكنده شدهاند (شكل (). همجنين بررسى ييكهاى اشعه ايكس نشان داد كه نمونه با باد خلوص بسيار بالايى در فاز كريستالى سنتز شده است. الكوى اشعه

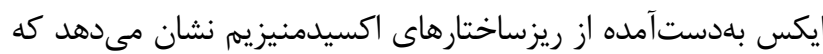

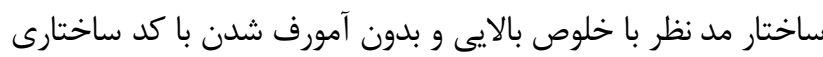

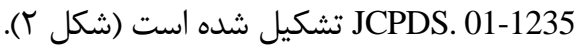

نتايج خواص ضد باكتريايى نانوذرات اكسيد منيزيم نانوذرات اكسيد منيزيوم سنتز شده بر عليه هر سه باكترى

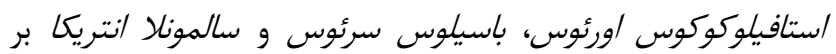

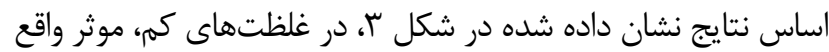
شدند. قطر هاله عدم رشد با افزايش غلظت نانوذرات اكسيد منيزيم رو به افزايش است .در جدول ا، ميانگين قطر هاله عدم رشد نانوذره اكسيد منيزيوم نسبت به سه باكترى و در جدول به به نتايج تجزيه واريانس ميانگين قطر عدم هاله رشد (ميلىمتر) بر اساس غلظت نانو ذره (ميلى

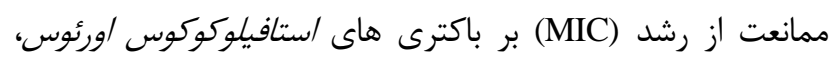
سالمونلا انتريكا و باسيلوس سرئوس به ترتيب VD • ••، ميلى گرم بر ميلىليتر و حداقل غلظت كشندگى (MBC) نانو ذرات

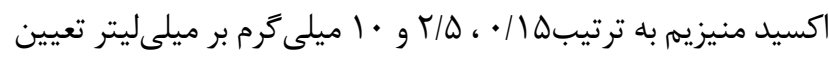

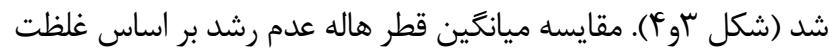
نانو ذره به روش دانكن در سطح ه •. •=له نشان مى دهد كه غلظتهاى به كار رفته بر روى ميانگين قطر هاله تفاوت معنىدارى داشته در خصوص باكترى /ستافيلوكوكوس اورئوس تا غلظت · •ا و در مورد باكترىهاى ديخر تا غلظت · ب ميلى گرم بر ميلى ليتر معنادار است. 
جدول ا. ميانگين قطر عدم هاله رشد (ميلىمتر) بر اساس غلظت ريز ذره (ميلى

\begin{tabular}{|c|c|c|c|c|}
\hline باكترى & ذلظت نانو & ميانكين & انتحراف اندار & خطاى استدارد \\
\hline \multirow{9}{*}{ استافيلوكوكوس } & $r \cdot$ & 0. & $1 / 21$ & $1 / \cdot$ \\
\hline & 1. & $\varepsilon V$ & $\cdot / N 1$ & $\cdot / 0$ \\
\hline & 0 & $\varepsilon r$ & $\cdot / N 1$ & $\cdot / 0$ \\
\hline & $r / 0$ & $\sum r$ & $\cdot / 99$ & $\cdot / \mathrm{v}$ \\
\hline & $1 / T 0$ & rv & $1 / T V$ & $\cdot / 9$ \\
\hline & $\cdot / 7 r$ & $r \cdot$ & $r / \Lambda \Gamma$ & $r / \cdots$ \\
\hline & $\cdot / \mu 1$ & ro & $T / M Y$ & $1 / 0$. \\
\hline &.$/ 10$ & r & $1 / 14$ & $\cdot / \wedge$ \\
\hline & $\cdot / \cdot$ vo & IT & $\cdot / N 1$ & $\cdot / 0$ \\
\hline \multirow{9}{*}{ سالمونلا انتريكا } & $r \cdot$ & $r \varepsilon$ & $\cdot / N 1$ & $\cdot / 0$ \\
\hline & 1. & 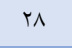 & $1 / 21$ & $1 / \cdots$ \\
\hline & 0 & $r$. & $1 / 1 r$ & $\cdot / \wedge$ \\
\hline & $T / O$ & 10 & $T / M T$ & $1 / 0$ \\
\hline & $\cdot / 7 r$ & 1. & $\cdot / 2 r$ & $\cdot / \pi$ \\
\hline & $\cdot / 7 r$ & · & · & $\cdot$ \\
\hline & $\cdot / 4$ & · & $\cdot$ & $\cdot$ \\
\hline &.$/ 10$ & · & · & · \\
\hline & $\cdot / \cdot v_{0}$ & · & · & $\cdot$ \\
\hline \multirow{9}{*}{ باسيلوس سرئوس } & $r \cdot$ & r. & $T / K T$ & $1 / 0$. \\
\hline & 1. & 10 & $1 / 21$ & $1 / \cdots$ \\
\hline & 0 & $1 \cdot \%$ & $\cdot / N 1$ & $\cdot 10$ \\
\hline & $T / 0$ & $\cdot$ & $\cdot$ & $\cdot$ \\
\hline & $\cdot / 7 r$ & . & $\cdot$ & $\cdot$ \\
\hline & $\cdot / 7 r$ & $\cdot$ & $\cdot$ & $\cdot$ \\
\hline & $\cdot \pi \mid$ & . & $\cdot$ & $\cdot$ \\
\hline &.$/ 10$ & . & $\cdot$ & $\cdot$ \\
\hline & $\cdot / \cdot v_{0}$ & . & · & · \\
\hline
\end{tabular}

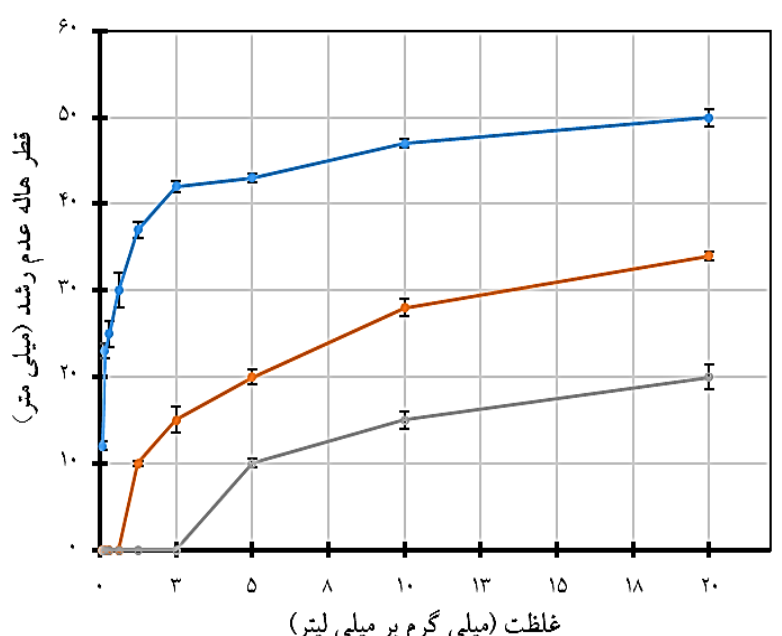

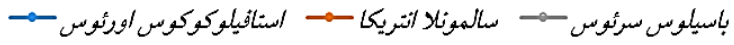
شكل F. مقايسه ميانگين قطر عدم هاله رشد (ميلىمتر) بر اساس غلظت نانوذره (ميلى گرم بر ميلىليتر).

\section{نتايج آنتى بيو}

نتايج حاصل از اثر آنتىبيوتيك ها بر سه بانت باكترى سويههاى

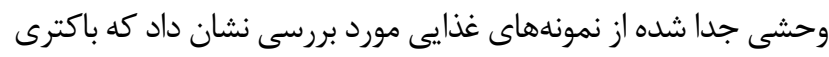

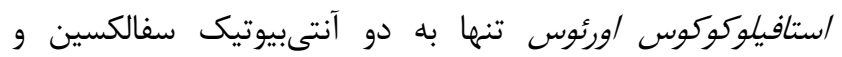

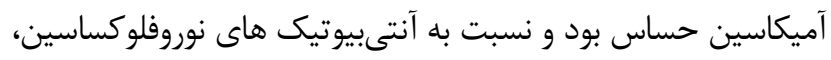
سيروفلوكساسين، جنتامايسين، آميىسيلين، سولفامتاكسازول و و

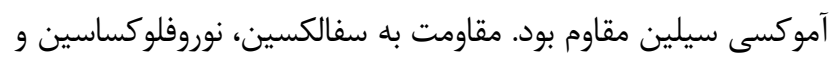

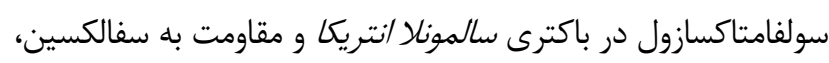
سولفامتاكسازول، آموكسى سيلين در مورد باكترى باسيلوس سرئوس مشاهده شد.

\begin{tabular}{|c|c|c|c|c|c|c|}
\hline باكترى & اختلاف & مجموع مربعات & درجه آزادى & ميانكين مربعات & 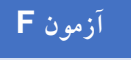 & سطح معنى دارى \\
\hline \multirow{3}{*}{ استافيلوكوكوس اورئوس } & بين كروه ها & ro7./... & $\wedge$ & $r r \cdot / \ldots$ & 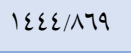 & $\cdot / \cdots$ \\
\hline & درون كروه ها & $19 / 11$. & 9 & $r / T \cdot q$ & & \\
\hline & كل & rova/M. & IV & & & \\
\hline \multirow{3}{*}{ سالمونلا انتريكا } & بين خروه ها & TVAO/VVA & $\wedge$ & TEN/TYT & $r V \cdot / \varepsilon \varepsilon q$ & $\cdot \cdots$ \\
\hline & درون كروه ها & $\Lambda / \varepsilon 7$ & 9 & $\cdot / 9 \varepsilon$ & & \\
\hline & كل & TVQE/TrA & IV & & & \\
\hline \multirow{3}{*}{ باسيلوس سرئوس } & بين كروه ها & $1 \cdots / \cdots$ & $\wedge$ & $1 r 0 / \cdots$ & $17 \cdot / N \mid \varepsilon$ & $\cdot / \cdots$ \\
\hline & درون گروه ها & $\mathrm{v} / \cdots$ & 9 & $\cdot / \mathrm{WA}$ & & \\
\hline & كل & $1 \cdots v / \cdots$ & IV & & & \\
\hline
\end{tabular}


سودوموناس آئروزينوزا و باكترىهاى كرممثبت استافيلوكوكوس

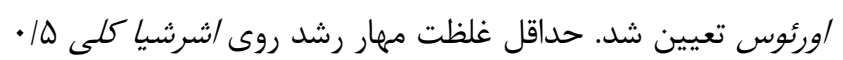

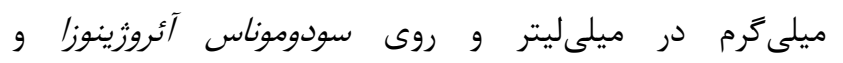

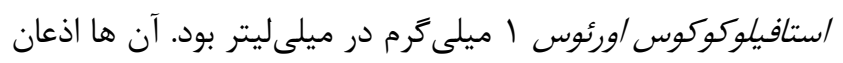

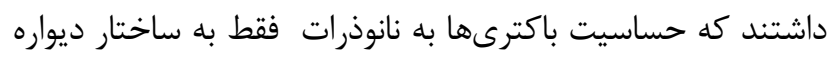

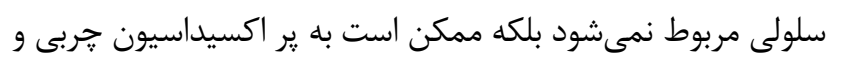

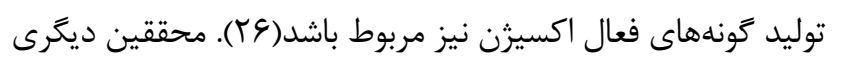

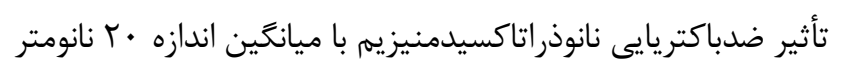

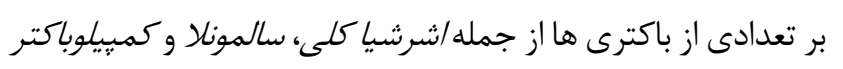

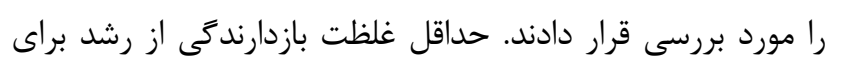

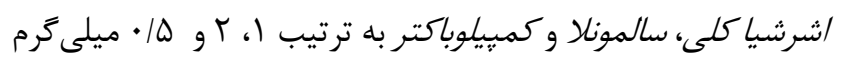

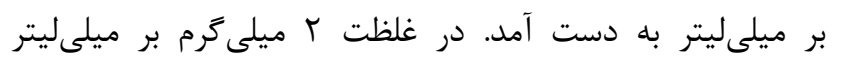

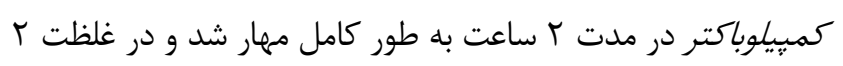

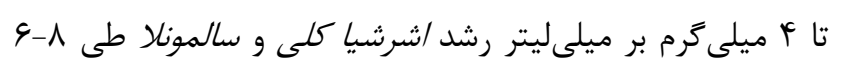

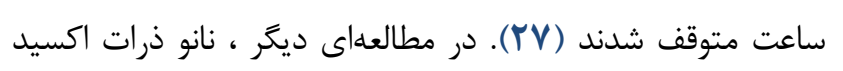

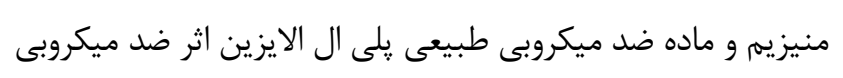

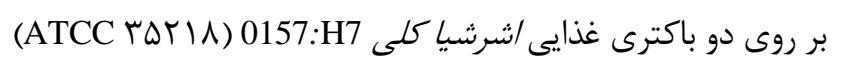

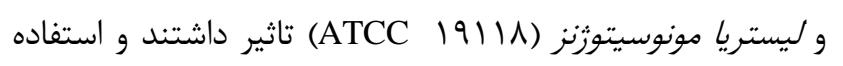
توأم آنها اثر همافزايى جزيى داشته و همجنينين باعث كاهش حداقل

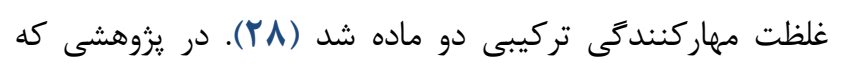

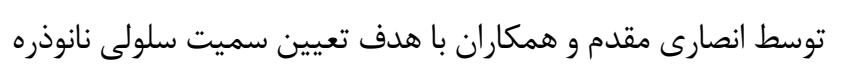

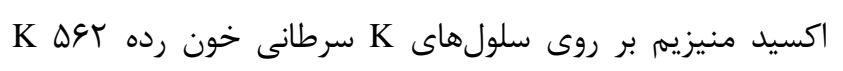

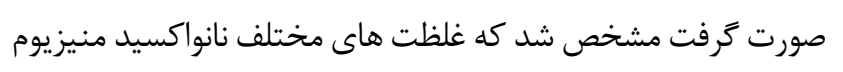

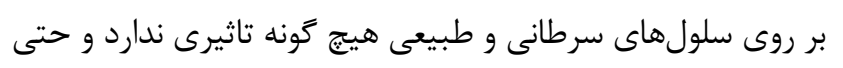

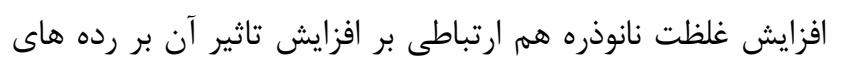

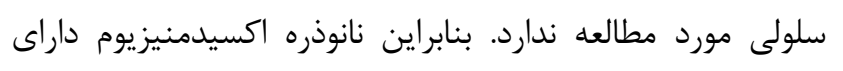
خاصيت سيتوتوكسيك بر سلولهاى انسانى نبوده و داراى اثرات

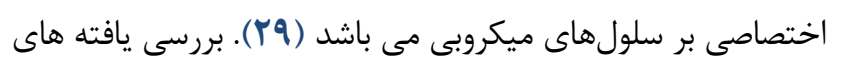

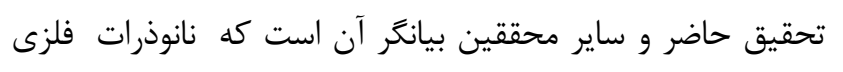

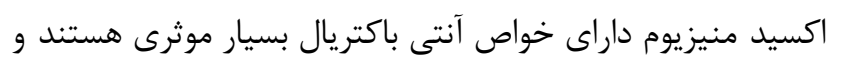

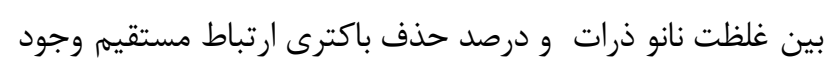

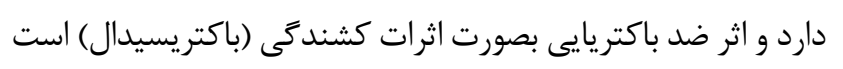

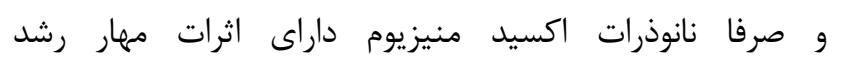

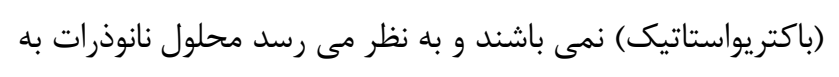

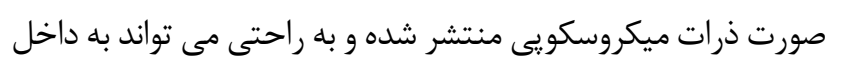

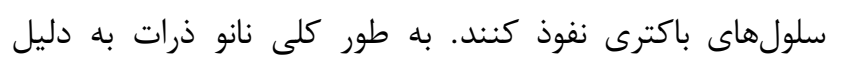

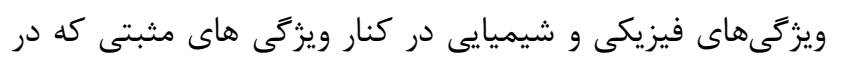

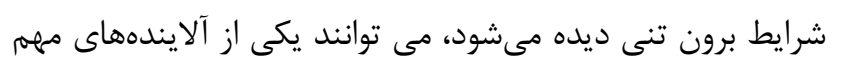

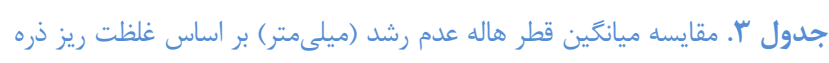

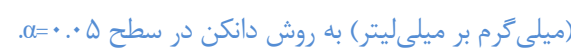

\begin{tabular}{|c|c|c|c|}
\hline غلظت & استافيلوكوكوس اورئوس & سالمونلا اتتريكا & باسيلوس سرئوس \\
\hline$r \cdot$ & a & a & $\mathbf{a}$ \\
\hline 1. & a & $\mathrm{b}$ & b \\
\hline 0 & $\mathrm{~b}$ & $\mathrm{c}$ & c \\
\hline$r / 0$ & $\mathrm{~b}$ & $\mathrm{~d}$ & d \\
\hline $1 / 70$ & $\mathrm{c}$ & e & d \\
\hline$\cdot / 7 r$ & d & $\mathrm{f}$ & d \\
\hline$\cdot / \mu 1$ & e & $\mathrm{f}$ & d \\
\hline$\cdot 110$ & $\mathrm{e}$ & $\mathrm{f}$ & d \\
\hline$\cdot / \cdot v_{0}$ & $\mathrm{f}$ & $\mathrm{f}$ & d \\
\hline \multicolumn{4}{|c|}{ حروف مشابه در هر گروه با هم تفاوت معنى دار ندارند. } \\
\hline
\end{tabular}

\section{بحث}

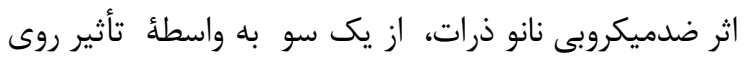

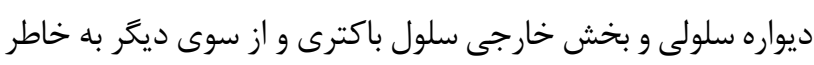

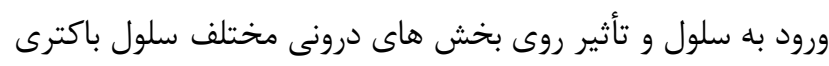

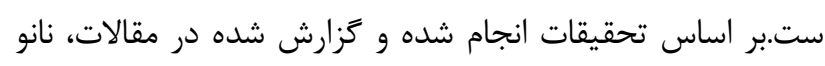

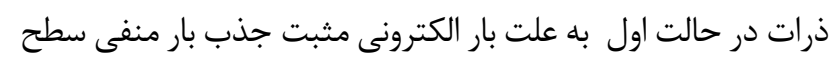

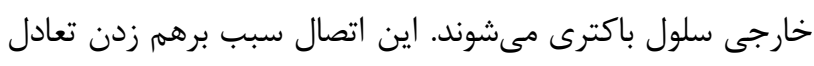

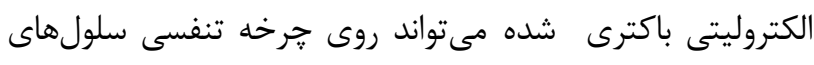

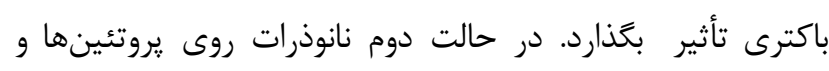

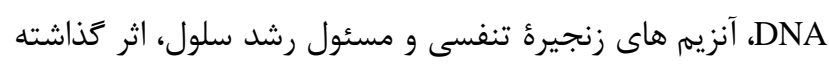

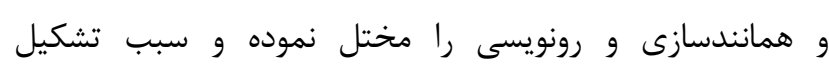

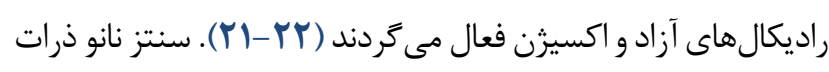

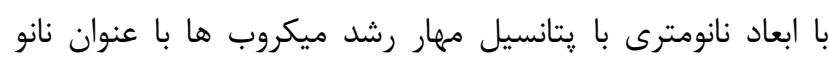

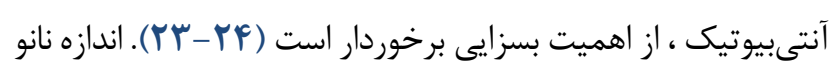

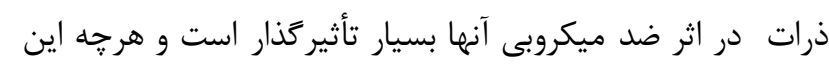

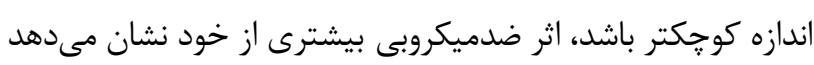

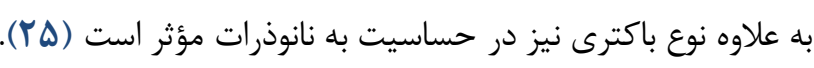

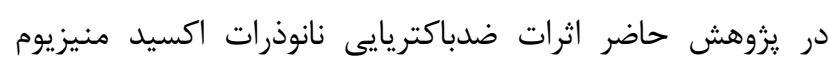

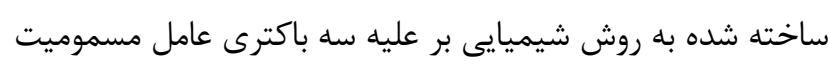

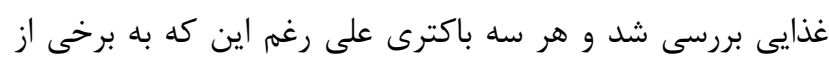

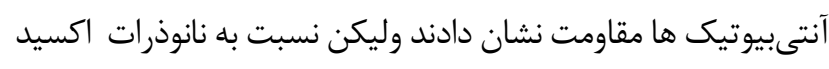
منيزيوم حتى در غلظت هاى بسيار كم حساس بودند. تحقيقات

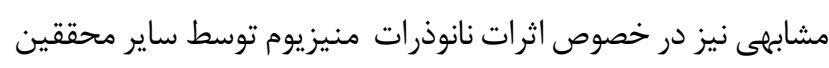

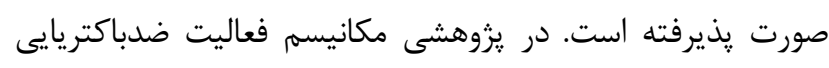

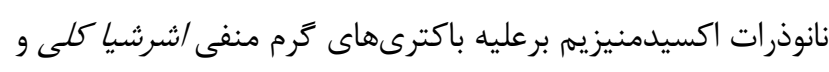




$$
\begin{aligned}
& \text { كانديداى مناسبى براى كنترل آلودگى هاى ميكروبى مواد غذايى در } \\
& \text { بسته بندى هاى ضدميكروبى موادغذايى در نظر گرفته شود. }
\end{aligned}
$$

$$
\begin{aligned}
& \text { سياسگزارى } \\
& \text { از همكاران محترم آزمايشگاه تحقيقاتى ميكروبيولوزى و حوزه }
\end{aligned}
$$

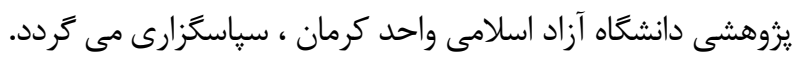

$$
\text { تعارض منافع }
$$

\section{Referance}

1. Ventola CL. The antibiotic resistance crisis: part 1: causes and threats. Pharmacy and Therapeutics. 2015;40(4):277.

2. Russell NJ, Gould GW. Food preservatives: Springer Science \& Business Media; 2003. [DOI:10.1007/978-0387-30042-9]

3. Udompijitkul P, Paredes Sabja D, Sarker MR. Inhibitory effects of nisin against Clostridium perfringens food poisoning and nonfood borne isolates. J Food Sci. 2012;77(1):M51-M6.

[DOI:10.1111/j.17503841.2011.02475.x] [PMID]

4. Kagan CR. At the nexus of food security and safety: opportunities for nanoscience and nanotechnology. ACS Publications; 2016. [DOI:10.1021/acsnano.6b01483] [PMID]

5. Hajipour MJ, Fromm KM, Ashkarran AA, de Aberasturi DJ, de Larramendi IR, Rojo T, et al. Antibacterial properties of nanoparticles. Trends Biotechnol. 2012;30(10):499-511.

[DOI:10.1016/j.tibtech.2012.06.004] [PMID]

6. Wang L, Hu C, Shao L. The antimicrobial activity of nanoparticles: present situation and prospects for the future. Int J Nanomedicine.. 2017;12:1227. [DOI:10.2147/IJN.S121956] [PMID] [PMCID]

7. Salata OV. Applications of nanoparticles in biology and medicine. J Nanobiotechnology. 2004;2(1):3. [DOI:10.1186/1477-3155-2-3] [PMID] [PMCID]

8. Nel A, Xia T, Mädler L, Li N. Toxic potential of materials at the nanolevel. science. 2006;311(5761):6227. [DOI:10.1126/science.1114397] [PMID]

9. Krishnamoorthy K, Moon JY, Hyun HB, Cho SK, Kim S-J. Mechanistic investigation on the toxicity of $\mathrm{MgO}$ nanoparticles toward cancer cells. J. Mater. Chem.. 2012;22(47):24610-7. [DOI:10.1039/c2jm35087d]
در ايجاد سميت بر عضوهاى مختلف بدن، نيز باشند، ارزيابى نوع مواجهه و شناسايى ويزگگىهاى خطر براى نانو ذرات، نيازمند در نظر

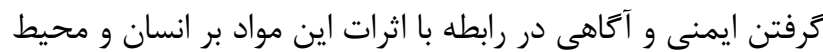
زيست، شناخت كامل مواد و اثرات سم شناسى آنهاست. نانو ذرات ، همانند يك شمشير دولبه داراى اثرات مفيد و مضر هستند .كر جه فناورى نانو باعث انقلاب و تحول گستردهاى در بسيارى از زمينهها شده است؛ با اينحال كاهش سميت و خطرات مواجهه با نانو ذرات بايستى از اهداف اصلى اين حوزه محسوب شود (•r-( (ب). نتيجه

با توجه به اثر ضدميكروبى كه نانوذرات اكسيد منيزيوم بر عليه

باكترى ها با منشا غذا از خود نشان داده است، مى تواند به به عنوان بان

10. Jin T, He Y. Antibacterial activities of magnesium oxide $(\mathrm{MgO})$ nanoparticles against foodborne pathogens. J Nanopart Res. 2011;13(12):6877-85. [DOI:10.1007/s11051-011-0595-5]

11. Hennekinne JA, De Buyser ML, Dragacci S. Staphylococcus aureus and its food poisoning toxins: characterization and outbreak investigation. FEMS Microbiol Rev. 2012;36(4): 815-836. [DOI:10.1111/j.1574-6976.2011.00311.x] [PMID]

12. Tewari A, Abdullah S. Bacillus cereus food poisoning: international and Indian perspective.J. food sci. technol. 2015;52(5):2500-11. [DOI:10.1007/s13197-014-13444] [PMID] [PMCID]

13. Eneroth Å, Svensson B, Molin G, Christiansson A. Contamination of pasteurized milk by Bacillus cereus in the filling machine. J Dairy Res. 2001;68(2):189-96. [DOI:10.1017/S002202990100485X] [PMID]

14. Kunwar R, Singh H, Mangla V, Hiremath R. Outbreak investigation: Salmonella food poisoning. Med J Armed Forces India.. 2013;69(4):388-91. [DOI:10.1016/j.mjafi.2013.01.005] [PMID] [PMCID]

15. Cushing BL, Kolesnichenko VL, O'Connor CJ. Recent advances in the liquid-phase syntheses of inorganic nanoparticles.Chem. Rev. 2004;104(9):3893-9. [DOI:10.1021/cr030027b] [PMID]

16. Cui H, Feng Y, Ren W, Zeng T, Lv H, Pan Y. Strategies of large scale synthesis of monodisperse nanoparticles. Recent Pat Nanotechnol. 2009;3(1):32-41. [DOI:10.2174/187221009787003302] [PMID]

17. Valgas C, Souza SMd, Smânia EF, Smânia Jr A. Screening methods to determine antibacterial activity of natural products. Braz J Microbiol. 2007;38(2):369-80. [DOI:10.1590/S1517-83822007000200034]

18. Nazoori ES, Kariminik A. In Vitro Evaluation of Antibacterial Properties of Zinc Oxide Nanoparticles on 
Pathogenic Prokaryotes. J Appl Biotechnol Rep. 2018;5(4):162-5. [DOI:10.29252/JABR.05.04.05]

19. Saha B, Bhattacharya J, Mukherjee A, Ghosh A, Santra C, Dasgupta AK, et al. In vitro structural and functional evaluation of gold nanoparticles conjugated antibiotics. Nanoscale Res. Lett. 2007;2(12):614. [DOI:10.1007/s11671-007-9104-2] [PMCID]

20. Bonev B, Hooper J, Parisot J. Principles of assessing bacterial susceptibility to antibiotics using the agar diffusion method. J. Antimicrob. Chemother. 2008;61(6):1295-301. [DOI:10.1093/jac/dkn090] [PMID]

21. Li WR, Xie XB, Shi QS, Zeng HY, You-Sheng OY, Chen YB. Antibacterial activity and mechanism of silver nanoparticles on Escherichia coli. Appl.microbiol.biotechnol. 2010 ; 85 (4) : 1115-22. [DOI:10.1007/s00253-009-2159-5] [PMID]

22. Panyala NR, Peña-Méndez EM, Havel J. Silver or silver nanoparticles: a hazardous threat to the environment and human health? J Appl Biomed. 2008 Sep 1;6(3). [DOI:10.32725/jab.2008.015]

23. Hoseynzadeh A, Khaleghi M, Sasan H. Investigating the Antimicrobial Effects of Silver Nanoparticles Synthesized by Bacteria Isolated From Agricultural Soils of Kerman, Iran. Iran J Med Microbiol. 2017 Nov 10;11(5):136-48. .

24. Dizaj SM, Lotfipour F, Barzegar-Jalali M, Zarrintan $\mathrm{MH}$, Adibkia K. Antimicrobial activity of the metals and metal oxide nanoparticles. Materials Science and Engineering: $\quad$ C. $2014 ; \quad 1 ; 44: 278-84$ [DOI:10.1016/j.msec.2014.08.031] [PMID]

25. Martinez-Castanon G, Nino-Martinez N, MartinezGutierrez F, Martinez-Mendoza J, Ruiz F. Synthesis and antibacterial activity of silver nanoparticles with different sizes. J Nanopart Res. 2008;10(8):1343-8. [DOI:10.1007/s11051-008-9428-6]

26. Krishnamoorthy K, Manivannan G, Kim SJ, Jeyasubramanian K, Premanathan M. Antibacterial activity of $\mathrm{MgO}$ nanoparticles based on lipid peroxidation by oxygen vacancy. J Nanopart Res . 2012;14(9):1063. [DOI:10.1007/s11051-012-1063-6]

27. Xie Y, He Y, Irwin PL, Jin T, Shi X. Antibacterial activity and mechanism of action of zinc oxide nanoparticles against Campylobacter jejuni. Appl. Environ. Microbiol. 2011;77(7):2325-31. [DOI:10.1128/AEM.02149-10] [PMID] [PMCID]

28. Samadi M, Shekarforoush SS, Ghaisari HR. Antimicrobial effects of magnesium oxide nanoparticles and $\varepsilon$-poly-L-lysine against Escherichia coli O157: H7 and Listeria monocytogenes. Iranian Journal of Medical Microbiology. 2016 Jul 15;10(2):33-41.

29. Ansari Moghaddam S, Rahmani F, Delirezh N. Investigating the effects of Magnesium Oxide
Nanoparticle Toxicity on K562 Blood Type Cancer Cells. Armaghane danesh. 2017 Dec 15;22(5):584-94.

30. Choi J, Wang NS. Nanoparticles in biomedical applications and their safety concerns. Biomedical engineering from theory to applications. 2011; 29:486. [DOI:10.5772/18452]

31. Jain A, Ranjan S, Dasgupta N, Ramalingam C. Nanomaterials in food and agriculture: an overview on their safety concerns and regulatory issues. Crit Rev Food Sci. 2018; 58(2):297-317. [DOI:10.1080/10408398.2016.1160363] [PMID] 